\title{
Desain Prototipe Sistem Konversi Energi Angin Skala Kecil Terhubung ke Baterai
}

\author{
Ratna Ika Putri ${ }^{1}$, M. Rifa' ${ }^{2}$, Eka Mandayatma ${ }^{3}$, Moch. Mustain $^{4}$, Abim Ridho $^{5}$ \\ 1,2,3,4,5 Jurusan Teknik Elektro, Politeknik Negeri Malang \\ Jl. Soekarno Hatta No. 9, Malang \\ Email: ratna.ika@polinema.ac.id
}

\begin{abstract}
Abstrak----Energi angin merupakan salah satu sumber energy terbarukan yang memiliki potensi besar di Indonesia untuk dikembangkan sebagai pengganti energy fosil yang semakin menipis. Penggunaan energi angin sangat dipengaruhi kecepatan angin yang berfluktuasi sehingga menghasilkan tegangan keluaran yang berfluktuasi pula. Untuk mengatasi hal tersebut dibutuhkan baterai sebagai penyimpan energi. Pada artikel ini kan dibahas mengenai desain prototipe sistem konversi energi angin dengan menggunakan permanent magnet synchronous generator (PMSG) skala kecil yang terhubung ke baterai. Sistem didesain dengan menggunakan mikrokontroller sebagai pengolah data yang mengatur kerja sistem keseluruhan dan menghasilkan sinyal pulse width modulation (PWM) untuk konverter. Pada saat putaran angin dapat menghasilkan tenaga listrik yang baik maka tegangan untuk beban akan disuplai dari prototipe turbin angin tersebut. Namun jika tenaga listrik turbin angin yang dihasilkan kecil, maka tegangan untuk beban akan disuplai dari baterai. Berdasarkan hasil pengujian, rangkaian konverter dapat mengatur pengisian dan pengosongan baterai pada sistem turbin angin berdasarkan pengukuran arus dan tegangan.
\end{abstract}

Kata Kunci : konverter, energi angin, mikrokontroler, baterai.

\begin{abstract}
Wind energy is one of the renewable energy sources that has great potential in Indonesia to be developed as a substitute for fossil energy that is running low. The use of wind energy is strongly influenced by fluctuating wind speeds so that it produces fluctuating output voltages as well. To overcome this we need batteries as energy storage. In this article, we will discuss the prototype design of a wind energy conversion system using a small scale permanent magnet synchronous generator (PMSG) connected to a battery. The system is designed by using a microcontroller as a data processor that regulates the overall system work and produces a pulse width modulation (PWM) signal for the converter. When the wind rotation can produce good electric power, the voltage for the load will be supplied from the prototype of the wind turbine. But if the wind turbine electricity produced is small, the voltage for the load will be supplied from the battery. Based on the test results, the converter circuit can regulate battery charging and discharging in the wind turbine system based on current and voltage measurements.
\end{abstract}

\section{Pendahuluan}

Pembangkit energi listrik terbesar saat ini didominasi oleh pembangkit listrik berbahan bakar batu bara yaitu sebesar $60 \%$ [1]. Dari besarnya presentasi pemanfaatan bahan bakar batu bara yang berasal dari fosil menyebabkan jumlahnya sembaterain berkurang. Pada tahun 2005 cadangan batu bara diperkirakan habis dalam kurun waktu 147 tahun dengan rasio cadangan atau produksi pada tahun tersebut[2]. Selain itu energi berbahan bakar menyebabkan pencemaran udara dan timbul efek rumah kaca dengan sembaterain banyaknya gas CO2 yang dikeluarkan. Oleh karena itu, dibutuhkan diversifikasi energi melalui energi terbarukan yang tidak terbatas jumlahnya dan tidak memiliki efek kerusakan terhadap alam. Salah satu energi terbarukan yang memiliki potensi besar di Indonesia adalah Pembangkit listrik tenaga angin. Angin tidak terbatas jumlahnya dan sangat mudah ditemukan sehingga sangat dapat dimanfaatkan.

Penggunaan energi angin sebagai energi alternatif memiliki keuntungan yaitu ramah lingkungan, bebas polusi emisi $\mathrm{CO} 2$, sumber daya yang tidak terbatas, handal dan mudah didapatkan [3][4]. Turbin angin beroperasi didalam dua mode yaitu fixed speed wind turbine (FSWT) atau variable speed wind turbine (VSWT). VSWT lebih efektif dibandingkan FSWT karena dapat mengoptimumkan konversi energi angin [5]. Turbin angin dengan kecepatan berubah didesain untuk mencapai efisiensi aerodinamik maksimum dengan jangkauan kecepatan angin yang lebar sehingga meningkatkan energi yang ditangkap, meningkatkan kualitas daya dan mengurangi rugi mekanik pada turbin angin[6]. Saat ini permanent magnet synchronous generator (PMSG) merupakan salah satu generator sinkron yang paling banyak digunakan pada aplikasi sistem VSWT karena memilliki beberapa keuntungan yaitu (1) tidak memerlukan sistem eksitasi eksternal, tidak terdapat rugi-rugi tembaga pada rangkaian rotor, biaya perawatan rendah dan kerapatan daya tinggi[7], (2) reliabilitas yang lebih baik, membutuhkan perawatan yang tidak rumit, ringan, volume rendah, performansi tinggi [8], (3) tidak membutuhkan gearbox sehingga dapat beroperasi pada kecepatan rendah dan menggurangi rugi-rugi, berat, dan biaya perawatan, (4) efisiensi tinggi[9], (5) Jika terdapat gangguan pada grid tidak berpengaruh secara langsung pada generator, (5) amplitudo dan frekuensi tegangan generator dapat dikontrol penuh oleh konverter [10]. Penggunaan PMSG pada turbin angin jenis variable speed 
akan lebih efektif dengan mengoptimalkan efisiensi sistem [11].

Namun sumber energi terbarukan termasuk energi angin sangat dipengaruhi oleh kondisi angin yang berubah-ubah sehingga dapat menyebabkan adanya fluktuasi daya disisi beban. Oleh karena itu, pada sistem turbin angin sangat dibutuhkan penyimpan energi listrik, seperti baterai yang dapat menjaga kestabilan daya disisi beban walaupun terjadi fluktuasi angin secara tiba-tiba. Penggunaan baterai pada sistem konversi energi angin dapat menyimpan kelebihan energi jika energi yang dihasilkan oleh turbin angin lebih besar dibandingkan dengan kebutuhan daya beban. Sedangkan pada saat kecepatan angin rendah dan kebutuhan beban tinggi maka baterai dapat mensuplai daya ke beban. Pada paper ini di desain sistem konversi energi angin menggunakan permanent magnet synchronous generator (PMSG) yang terhubung ke baterai dan beban berupa lampu DC. Mikrokontroler digunakan untuk mengatur kerja dari sistem secara keseluruhan. Tegangan keluaran PMSG terhubung dengan rangkaian penyearah tiga fasa. Arus dan tegangan keluaran penyearah dan konverter dideteksi oleh sensor arus dan tegangan untuk menentukan duty cycle sinyal PWM yang dikirimkan ke konverter.

\section{Sistem TURBIN ANGIN DENGAN PMSG}

Berdasarkan kecepatan rotasi, turbin angin dibagi menjadi dua yaitu kecepatan tetap (fixed speed wind turbine) dan kecepatan berubah (variable speed wind turbine). Fixed speed wind turbine (FSWT) disebut juga dengan konsep Danish yang sangat populer pada tahun 1980-an [12]. FSWT memiliki keuntungan yaitu merupakan sistem yang sederhana dan banyak digunakan karena biaya perawatan yang rendah dengan mengurangi penggunaan rangkaian elektronika daya yang mahal seperti inverter dan konverter. Namun dengan kecepatan yang konstan maka turbin tidak dapat beroperasi pada efisiensi puncak dengan kecepatan angin yang berubah sehingga energi yang dihasilkan kecil. FSWT menghasilkan fluktuasi daya keluaran ke grid yang tinggi sehingga menyebabkan gangguan ke sistem daya. Turbin jenis ini juga membutuhkan desain mekanik yang kokoh dan mahal untuk dapat menyerap tekanan mekanik yang tinggi.

Variable speed wind turbine (VSWT) dapat mencapai efisiensi konversi energi angin maksimum pada jangkauan kecepatan angin yang lebar. Untuk mencapai efisiensi konversi daya maksimum pada kecepatan angin berbeda yaitu dengan mempertahankan tip speed ratio (TSR) pada kondisi optimal. Generator turbin angin pada VSWT dihubungkan ke grid melalui sistem konverter daya. Sistem konverter mengaktifkan kontrol kecepatan generator yang secara mekanik dikopel pada rotor turbin angin. Keuntungan utama VSWT yaitu meliputi peningkatan keluaran energi angin, meningkatkan kualitas daya dan mengurangi stres mekanik. Dibandingkan sistem FSWT, sistem VSWT dapat menangkap energi angin 5\% lebih besar dan daya aktif dan reaktif yang dihasilkan dapat dengan mudah dikontrol. Kekurangan sistem ini yaitu biaya yang lebih tinggi karena penggunaan konverter daya sehingga meningkatkan rugirugi daya dan kompleksitas pengontrolan. Walaupun hal tersebut dikompensasi dengan produksi energi yang lebih tinggi. Biaya untuk konverter elektronika daya dapat mencapai sekitar 7\% dari keseluruhan biaya sistem turbin angin[12]

Untuk mengkonversi energi mekanik menjadi energi listrik membutuhkan generator listrik. Permanent Magnet Synchronous Generator (PMSG) merupakan salah satu jenis generator sinkron yang banyak diaplikasikan pada sistem turbin angin dikarenakan memiliki beberapa kelebihan antara lain ukurannya yang kecil, memiliki kehandalan yang tinggi, tidak butuh pemeliharaan yang rumit, serta kerapatan daya yang lebih tinggi karena tidak memiliki belitan rotor. Jenis generator ini juga tidak memerlukan sistem eksitasi karena sumber eksitasi disediakan oleh magnet permanen yang berada pada rotor. Selain itu, desain yang sederhana dengan rotor tanpa kumparan medan, slip ring, dan tanpa sistem eksitasi juga membuat PMSG dapat meningkatkan efisiensi pada mesin. PMSG digunakan untuk aplikasi pada turbin tenaga angin yang rendah.

Prototipe sistem turbin angin pada artikel ini menggunakan Permanent Magnet Synchronous Generator (PMSG) 500Watt yang dilengkapi dengan emulator wind turbine. Emulator wind turbine terdiri dari motor induksi tiga fasa yang terhubung ke variable speed drive untuk mengatur kecepatan motor induksi. Emulator wind turbine berfungsi untuk mensimulasikan kecepatan angin dan putaran turbin sehingga generator akan berputar sesuai dengan kecepatan angin yang dihasilkan. Sembaterain tinggi kecepatan angin maka putaran generator akan sembaterain besar.

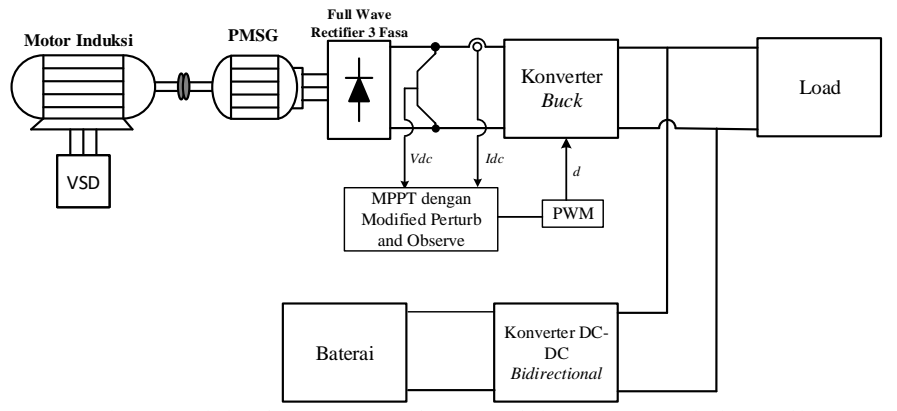

Gambar 1. Blok Diagram Prototipe Standalone VSWT Skala Kecil

Pada prototipe sistem turbin angin menggunakan PMSG, tegangan dari ganerator akan masuk menuju rangkaian penyearah tiga fasa tidak terkendali dan filter yang akan merubah tegangan AC menjadi tegangan DC. Sembaterain tinggi putaran kecepatan generator maka tegangan AC yang dihasilkan juga akan sembaterain besar. Gambar 1 menunjukkan blok diagram prototipe sistem turbin angin dengan PMSG yang terdiri dari emulator wind turbine, PMSG, penyearah tiga fasa, buck konverter, mikrokontroler dan beban.

\section{DESAIN PROTOTIPE SISTEM KONVERSI ENERGI ANGIN DENGAN PMSG}

Salah satu kelemahan system turbin angina adalah fluktuasi daya yang dihasilkan karena daya yang dihasilkan tergantung pada kecepatan angin yang berfluktuasi. Hal ini dapat mempengaruhi pemenuhan kebuthan beban, sehingga diperlukan system penyimpan energi seperti baterai, baterai dan sebagai nya untuk dapat mempertahankan suplai daya dan tegangan ke beban tetap konstan. Untuk itu diperlukan konverter bidirectional yang terhubung dengan system turbin angina dan baterai sebagai penyimpan energi. Prototipe yang 
telah dikembangkan ini dihubungkan dengan konverter bidirectional untuk pengisian dan pengosongan baterai yang digunakan sebagai penyimpan energi dan sumber daya untuk beban. Pada saat generator menghasilkan daya yang lebih rendah dari kebutuhan beban maka baterai akan bekerja pada mode pengosongan untuk mensuplai daya ke beban. Sedangkan pada saat daya yang dihasilkan generator melebihi kebutuhan beban maka konverter bidirectional akan beroperasi untuk pengisian baterai. Gambar 2 menunjukkan sistem pengisian baterai pada prototipe sistem turbin angin dengan menggunakan konverter. Sistem terdiri dari sensor arus, sensor tegangan, relay, konverter, mikrokontroler ATmega, rangkaian penggerak Mosfet dan baterai. Tegangan keluaran PMSG yang dapat diproses adalah 20 - 100 Volt, jika tegangan kurang dari atau lebih dari batas tersebut maka relay akan memutus tegangan menuju penyearah. Sedangkan batas tegangan pada buck converter adalah 0-25 Volt. Keluaran tegangan listrik dari turbin akan dibuat stabil dengan mengunakan rangkaian DC to DC Converter yaitu buck converter. Kontrol switching pada rangkaian buck coverter menggunakan Microkontroller ATMEGA melalui rangkaian penggerak Mosfet

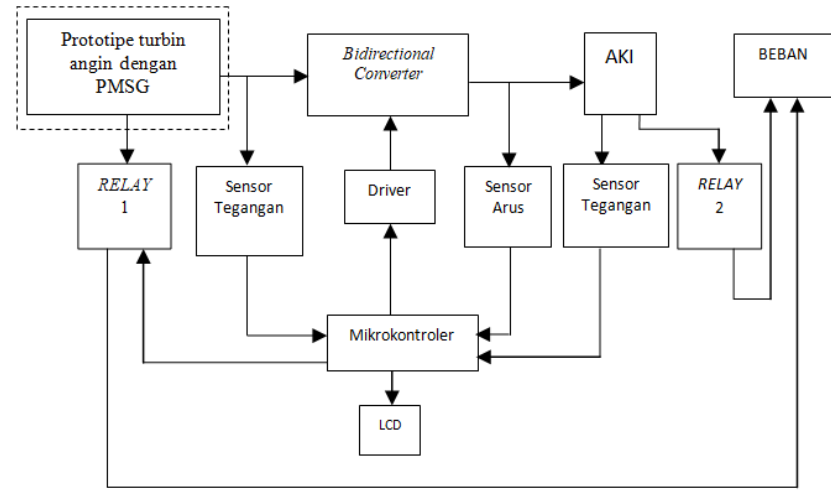

Gambar 2. Blok Diagram Alat

Gambar 2 menunujukkan blok diagram alat yang terdiri dari prototype turbin angina dengan PMSG, konverter, Sensor Arus, Sensor Tegangan, Arduino, Driver Mosfet, Baterai, Relay, modul wifi, LCD, dan lampu DC sebagai beban akhir. Prinsip kerja dari penelitian ini adalah untuk mengatur tegangan pada sistem charge dan discharge baterai yang berasal dari sumber energi terbarukan, yaitu turbin angin. Rangkaian Bidirectional konverter ini dipilih karena dapat menyesuaikan pada saat mode pengisian maupun pengosongan. Konverter ini menggunakan sinyal pulse width modulation (PWM) untuk meraih hasil yang maksimal. Nilai tegangan keluaran konverter ditentukan oleh besarnya duty cycle sinyal PWM yang diberikan ke konverter. Sedangkan untuk menentukan besaran nilai pwm yang akan digunakan, maka dilakukan identifikasi menggunakan sensor tegangan dan sensor arus. Ketika sistem turbin angin berjalan dan mengeluarkan output $14 \mathrm{~V}$, maka proses pengisian baterai akan berlangsung bersamaan dengan pemanfaatan keluaran turbin angin untuk beban lampu. Pada sistem pengisian, penggunaan nilai pwm akan berbeda dengan saat sistem pengosongan. Selama proses pengisian sampai dengan pengosongan sensor tegangan dan arus terus bekerja untuk melakukan monitoring kinerja rangkaian konverter tersebut.

\section{A. Desain Sensor Tegangan}

Sensor tegangan berfungsi untuk mendeteksi tegangan keluaran konverter pada prototipe turbin angin dan tegangan masukan pada baterai. Rangkaian sensor tegangan ini akan mengkonversi tegangan keluaran konverter menjadi tegangan DC yang sesuai dengan kebutuhan Analog to Digital Conversion (ADC) pada mikrokontroler. Sensor tegangan ini memilikijangkauan tegangan masukan sebesar $0-25$ volt. Sedangkan jangkauan tegangan masukan pada ADC mikrokontroler sekitar $0-5$ volt.

Rangkaian sensor tegangan menggunakan prinsip dasar rangkaian listrik voltage divider atau pembagi tegangan untuk menurunkan tegangan pada prototipe sistem turbin angin yang kemudian masuk ke ADC mikrokontroler. Gambar 3 menunjukkan rangkaian sensor tegangan yang digunakan pada peralatan ini.

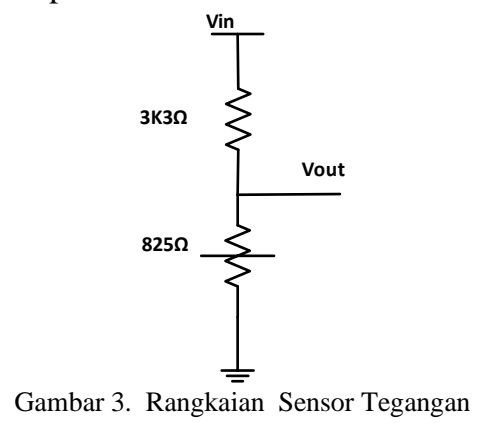

Jika tegangan masukan pada rangkaian sensor tegangan sebesar 25 volt maka harus menghasilkan tegangan keluaran sebesar 5 volt. Besarnya tegangan keluaran rangkaian ditentukan dengan persamaan

$$
\begin{aligned}
\text { Vout } & =\frac{R 2}{R 2+R 1} \times \text { Vin } \\
5 & =\frac{R 2}{R 2+R 1} \times 25
\end{aligned}
$$

Jika menggunakan R1 sebesar 3K3 ohm maka besarnya nilai R2 sebesar $825 \Omega$ dan sesuai dengan komponen yang ada dipasaran dapat digunakan potensiometer sebesar $1 \mathrm{~K} \Omega$

\section{B. Desain Sensor Arus}

Sensor arus berfungsi untuk mendeteksi besarnya arus keluaran konverter bidirectional. Sensor arus terhubung ke mikrokontroler melalui ADC yang akan mengkonversi menjadi sinyal digital. Sensor arus yang digunakan adalah sensor arus jenis IC ACS712. Pada datasheet IC ACS 712 dapat dilihat bahwa hasil pembacaan dari sensor arus berupa tegangan DC dengan kondisi awal (arus input $=0$ ) menghasilkan tegangan keluaran sebesar 1,5 volt dengan tegangan referensi sebesar 3 volt. Pada artikel ini menggunakan tipe sensor ACS-712ELCTR-05B-T yang memiliki rating pembacaan arus maksimal 5 Ampere. Hal ini dikarenakan jangkauan pengukuran arus tidak melebihi 5A. Gambar rangkaian ACS712 ditunjukkan oleh Gambar 4. Nilai ADC yang dihasilkan dari penbacaan keluaran sensor arus dapat dinyatakan dengan persamaan :

$$
A D C(\text { teori })=\left(\frac{2^{n}}{V R}\right) \times \operatorname{Vin}
$$




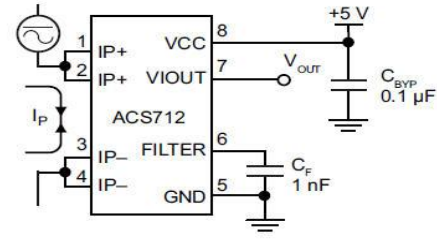

Gambar 4. Rangkaian ACS 712.

\section{Desain Konverter}

DC/DC Converter (BDC) merupakan perangkat konversi level tegangan DC yang dapat mengalirkan daya dari sisi sumber menuju sisi beban, maupun sebaliknya. Konverter jenis ini banyak digunakan pada berbagai macam aplikasi seperti uninterruptable power supplies (UPS), perangkat isi ulang baterai cerdas, dan hybrid energi storage sistem (HESS) pada berbagai macam bidang, seperti perindustrian, perangkat elektronik, dan kendaraan listrik [13].

Pada umumnya, DC-DC konverter dapat dibagi menjadi tipe nonisolated dan tipe isolated. Sebuah konverter termasuk dalam tipe nonisolated apabila antara input dan output memiliki hubungan sirkuit listrik. Tipe ini memiliki rangkaian yang sederhana dan skema kontrol yang mudah. Namun, apabila input dan output nya terpisah atau tidak memiliki hubungan sirkuit listrik, maka konverter tersebut termasuk tipe isolated. Pada umumnya untuk tipe isolated, input dan output dipisahkan dengan menggunakan transformator berfrekuensi tinggi. Hal ini memberikan perlindungan lebih pada sisi beban yang tidak diberikan di tipe non-isolated. Namun rangkaian akan sembaterain kompleks dan skema kontrol yang rumit [14]. Untuk konverter dc tipe non-isolated secara umum terdapat 3 jenis topologi berdasarkan fungsinya, yaitu konverter buck, konverter boost, dan konverter buck-boost. Konverter buck berfungsi untuk menurunkan tegangan, konverter boost berfungsi untuk menaikkan tegangan, dan konverter buckboost berfungsi ganda yaitu menaikkan atau menurunkan tegangan [15].

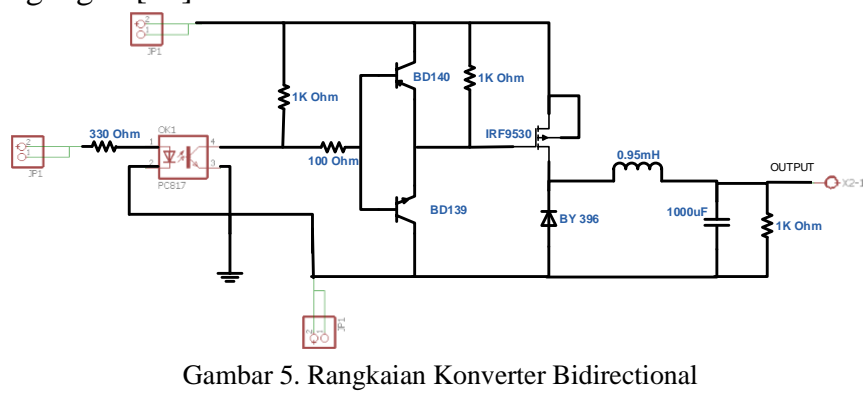

Gambar 5 menunjukkan rangkaian konverter bidirectional yang didesain pada artikel ini. Rangkaian konverter akan menghasilkan tegangan keluaran yang lebih besar atau lebih kecil dari masukan yang dihasilkan. Pada saat tegangan keluaran prototype turbin angina lebih dari $14 \mathrm{~V}$ maka rangkaian akan bekerja pada mode pengisian. Namun sebaliknya jika tegangan keluaran prototipe kurang dari $14 \mathrm{~V}$ maka rangkaian akan bekerja sebagai mode pengosongan. Rangkaian konverter terdiri dari rangkaian optocoupler, rangkaian totem pole, Mosfet, inductor, kapasitor dan resistor. Pengaturan besar tegangan keluaran rangkaian konverter melalui pengaturan sinyal pulse width modulation (PWM) yang diberikan pada Mosfet. Sinyal PWM dihasilkan oleh mikrokontroler sebagai pusat pengolah data. Rangkaian Optocoupler berfungsi sebagai antar muka antara mikrokontroler dengan rangkaian totem pole sebagai rangkaian penggerak Mosfet. Pada saat mikrokontroler berlogika 1 dengan tegangan keluaran sebesar 4.8V. Dengan tegangan jatuh dan arus LED pada optocoupler sebesar $1.5 \mathrm{~V}$ dan $15 \mathrm{~mA}$, R1 yang dipasang untuk meghambat arus yang mengalir pada optocoupler, dapat ditentukan sebesar

$$
\begin{aligned}
& R_{1}=\frac{V_{O H}-V_{L E D}}{I_{\text {LED }}} \\
& R_{1}=\frac{4,8 \mathrm{~V}-1,5 \mathrm{~V}}{15 \mathrm{~mA}}=320 \Omega
\end{aligned}
$$

Nilai R1 yang harus dipasang sebesar $330 \Omega$ menyesuaikan nilai resistor yang ada di pasaran.

Rangkaian totem pole terdiri dari dua transistor sejenis yang saling berlawanan yaitu NPN dan PNP. Rangkaian ini berfungsi sebagai penggerak Mosfet dan juga sebagai pengaman. Pada rangkaian konverter ini menggunakan transistor BJT dengan tipe BD140 dan BD139. Tipe Mosfet yang digunakan IRF9530.

\section{Rangkaian Relay}

Gambar 6 menunjukkan rangkaian relay yang berfungsi untuk memutus atau menyambung antara beban, prototipe turbin angin dan baterai. Pada sistem ini terdiri dari dua buah relay yang bekerja bergantian. Relay 1 menghubungkan prototipe dan beban sedangkan relay 2 menghubungkan baterai dan beban. Relay 1 akan memutus hubungan ke beban jika tegangan yang dihasilkan oleh sistem turbin angin kurang dari $3 \mathrm{~V}$ dan beban akan disuplai sepenuhnya oleh baterai. Jika beban tidak membutuhkan suplai daya maka relay 2 akan aktif untuk memutus hubungan antara baterai dan beban. Relay yang digunakan adalah SPDT $5 \mathrm{~V}$.

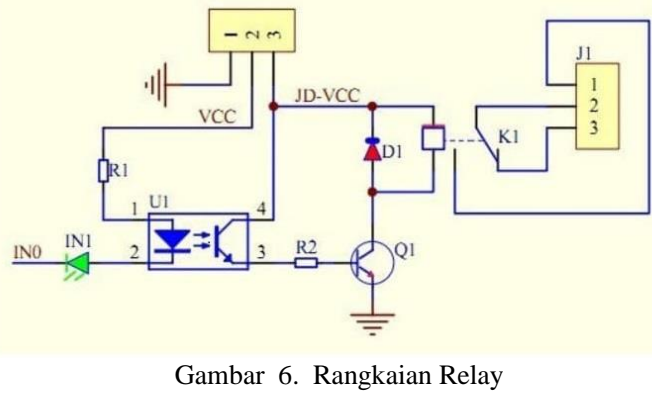

Cara kerja rangkaian relay ini aktif ketika kondisi low"0". Yaitu ketika masukan pada photocoupler berlogika " 0 ", dalam kondisi rendah, maka akan mengaktifkan phototransistor sehingga arus akan mengalir dari kolektor menuju emitor. Selanjutnya arus mengalir menuju resistor sebelum masuk ke basis transistor, hal ini bertujuan untuk membatasi arus agar tidak berlebih. Adanya arus basis transistor akan mengaktifkan transistor dan membuat kumparan pada relay akan teraliri arus listrik dan menghasilkan medan magnet yang dapat menggerakkan mekanik pada relay tersebut.

Berdasarkan datasheet arduino, tegangan output dari arduino adalah Varduino $=5 \mathrm{~V}$, sedangkan pada datasheet optocoupler PS2705 dengan tegangan Vf maks $=1.5 \mathrm{~V}$ dan If 
$=20 \mathrm{~mA}$, maka nilai $\mathrm{R}$ yang digunakan dapat ditentukan berdasarkan persamaan (3) sebesar $180 \Omega$

Sedangkan untuk perhitungan nilai $\mathrm{R}$ yang terhubung dengan transistor BJT, dengan tegangan catu daya (VCC) sebesar $5 \mathrm{~V}$ dan arus kolektor dari optocoupler berdasarkan datasheet adalah sebesar 50mA, dapat ditentukan dengan persamaan

$$
\begin{aligned}
& \mathrm{Vcc}-\mathrm{VCE}-\mathrm{VR} 2-\mathrm{VBE}=0 \\
& 12 \mathrm{~V}-2 \mathrm{~V}-\mathrm{Ib} \mathrm{R} 2-0.7 \mathrm{~V}=0
\end{aligned}
$$

Nilai R2 yang digunakan sebesar $120 \Omega$

\section{E. Desain Mikrokontroler}

Rangkaian mikrokontroler berfungsi sebagai pengolah data dan mengatur keseluruhan proses dari sistem ini, seperti yang ditunjukkan pada Gambar 7. Mikrokontroler yang digunakan pada artikel ini yaitu arduino. Arduino akan menghasilkan duty cycle sinyal PWM yang digunakan untuk mengaktifkan Mosfet pada rangkaian konverter bidirectional. Duty cycle ditentukan berdasarkan pengukuran arus dan tegangan oleh sensor. Selain itu arduino juga akan menampilkan hasil pengukuran arus dan tegangan melalui liquid crystal display (LCD) dan juga mengatur kerja dari relay. Sensor arus dan tegangan terhubung pada pin analog dari mikrokontroler. Penggunaan pin pada mikrokontroler ditunjukkan pada Tabel 1.

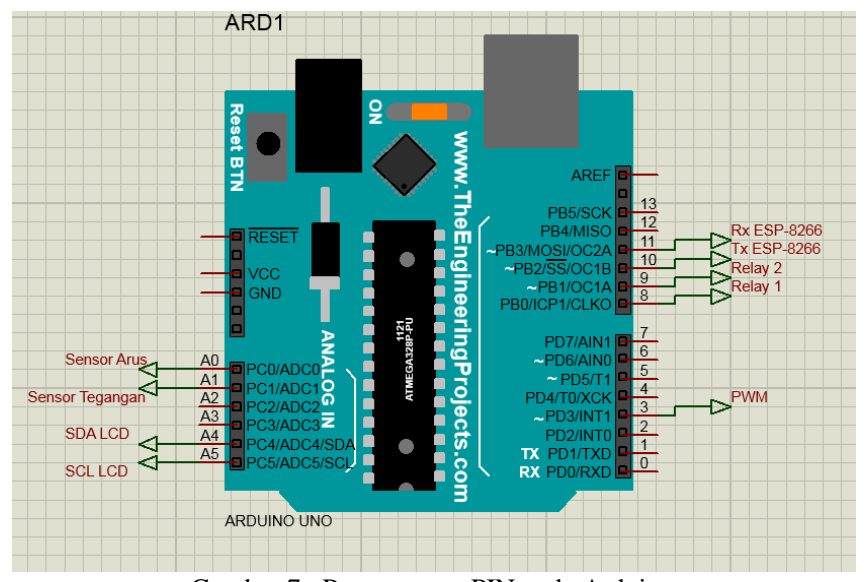

Gambar 7. Perancangan PIN pada Arduino

Tabel 1. Penggunaan PIN pada Arduino

\begin{tabular}{ll}
\hline \multicolumn{1}{c}{ Pin } & \multicolumn{1}{c}{ Fungsi } \\
\hline PIN 3 & PWM konverter \\
PIN 8 & Relay 2 \\
PIN 9 & Relay 1 \\
PIN A0 & Sensor Arus \\
PIN A1 & Sensor Tegangan \\
PIN A4 & SDA I2C LCD \\
PIN A5 & SCL I2C LCD
\end{tabular}

\section{HASIL DAN PEMBAHASAN}

Analisa performansi kinerja sistem turbin angin dengan rangkaian konverter untuk pengisian baterai dilakukan melalui pengujian sistem. Berdasarkan pengukuran langsung dilapangan, hubungan antara kecepatan angin dan kecepatan putar generator ditunjukkan pada Gambar 8. Kecepatan generator sebanding dengan kecepatan angin [4-6]. Berdasarkan hasil pengukuran, semakin tinggi kecepatan angin maka kecepatan generator akan semakin tinggi pula.

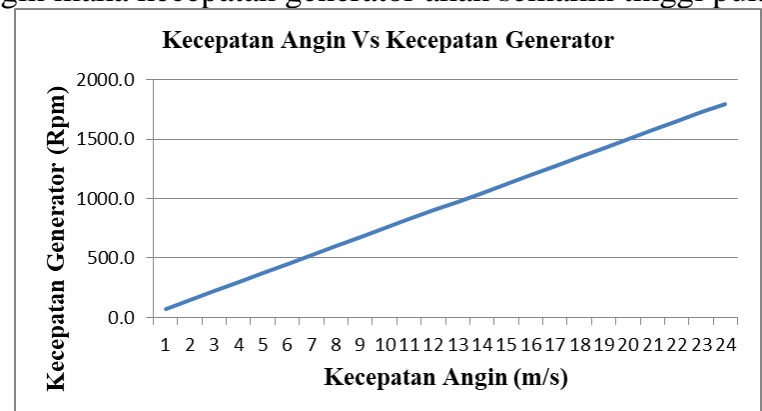

Gambar 8. Hasil Pengukuran Hubungan Kecepatan Angin Dan Kecepatan Generator

Peningkatan kecepatan generator akan menghasilkan peningkatan tegangan keluaran generator sehingga tegangan yang dihasilkan oleh turbin angin akan meningkat. Tegangan keluaran konverter akan dideteksi oleh sensor tegangan. Gambar 9 menunjukkan hasil pengujian sensor tegangan.tegangan keluaran sensor tegangan yang linier terhadap tegangan masukan. Jangkauan tegangan keluaran yang dihasilkan antara $0 \mathrm{~V}$ hingga $5 \mathrm{~V}$ sesuai dengan jangkauan masukan ADC pada mikrokontroler.

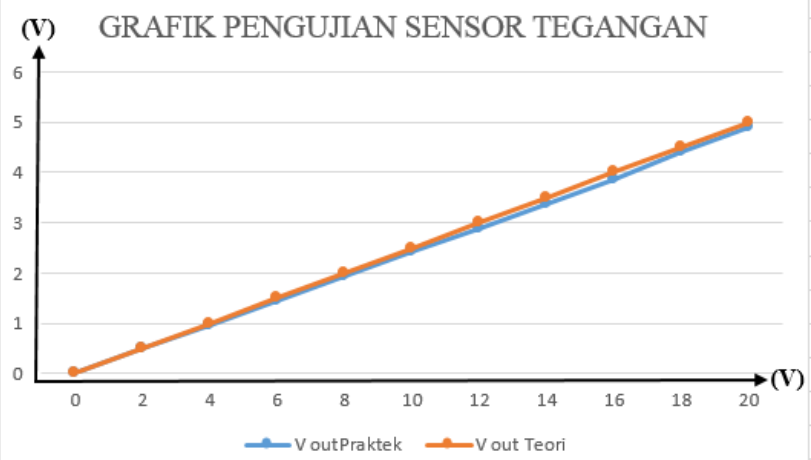

Gambar 9. Hasil Pengujian Sensor Tegangan

Berdasarkan hasil pengujian, semakin besar tegangan yang dideteksi sensor maka akan menghasilkan tegangan keluaran yang semakin besar pula. Sensor tegangan mampu mendeteksi tegangan keluaran konverter dan menghasilkan tegangan keluaran yang sesuai dengan kebutuhan ADC dengan rata-rata error sebesar $2.75 \%$. Gambar 10 menunjukkan hasil pengujian sensor arus ACS712. Pengujian sensor arus ini bertujuan untuk mengetahui kinerja sensor arus. Pengujian dilakukan pada peralatan turbin angin yang telah didesain dan memberikan variasi perubahan arus yang diukur dan dibandingkan dengan alat ukur ampermeter standar. Detektor arus diuji menggunakan variasi arus dari 0 hingga 5A dengan kenaikan setiap 0,5A. 


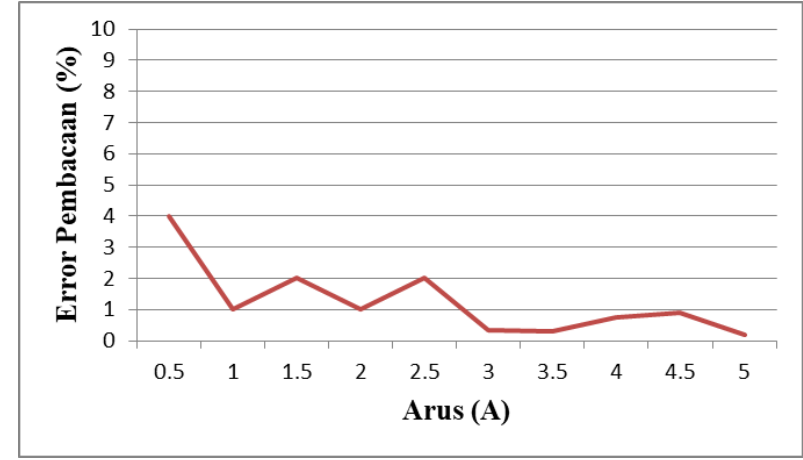

Gambar 10. Hasil Pengujian Sensor Arus

Berdasarkan hasil pengujian, dapat terlihat dengan perubahan nilai arus yang bervariasi dari $0 \mathrm{~A}$ hingga $5 \mathrm{~A}$ menghasilkan error maksimum sebesar $4 \%$ pada pengukuran arus 0,5A. Error pembacaan arus semakin kecil dengan pengukuran arus yang semakin besar. Rata-rata error pembacaan yang dihasilkan sebesar 3,94\%.

Untuk mengevaluasi kinerja konverter dilakukan pengujian dengan memberikan perubahan duty cycle, seperti yang ditunjukkan pada gambar 11. Pada saat duty cycle dibawah $40 \%$, tegangan keluaran di bawah tegangan masukan yang diberikan. Sebaliknya pada saat duty cycle diatas $40 \%$, tegangan keluaran yang dihasilkan sama dengan tegangan masukan.

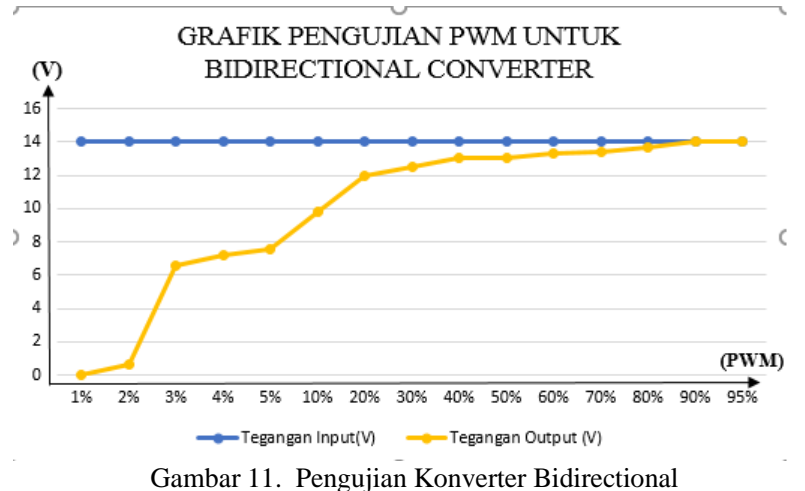

Pengujian sistem keseluruhan dilakukan untuk mengetahui kinerja konverter pada pengisian baterai. Baterai yang digunakan adalah $12 \mathrm{~V} 45 \mathrm{AH}$. Baterai dihubungkan dengan beban lampu DC. Hasil pengujian konverter untuk pengisian baterasi seperti yang ditunjukkan pada tabel 2 . Pada kondisi awal, baterai dalam kondisi penuh dan tegangan baterai dapat dijaga konstan pada $13 \mathrm{~V}$. Pada saat beban meningkat, arus baterai akan menurun, namun rangkaian konverter bekerja untuk mensuplai baterai sehingga tegangan dapat dipertahankan konstan.

Tabel 2. Hasil Pengujian konverter untuk Pengisian Baterai

\begin{tabular}{cccc} 
Jam & Tegangan Input & Tegangan Baterai & Arus Baterai \\
(WIB) & $14.00 \mathrm{~V}$ & $13.04 \mathrm{~V}$ & $1.33 \mathrm{~A}$ \\
\hline 13.26 & $14.00 \mathrm{~V}$ & $13.12 \mathrm{~V}$ & $1.32 \mathrm{~A}$ \\
13.58 & $14.00 \mathrm{~V}$ & $13.20 \mathrm{~V}$ & $1.32 \mathrm{~A}$ \\
14.24 & $14.00 \mathrm{~V}$ & $13.28 \mathrm{~V}$ & $1.26 \mathrm{~A}$
\end{tabular}

$\begin{array}{llll}15.20 & 14.00 \mathrm{~V} & 13.36 \mathrm{~V} & 1.24 \mathrm{~A} \\ 15.41 & 14.00 \mathrm{~V} & 13.44 \mathrm{~V} & 1.12 \mathrm{~A} \\ 15.55 & 14.00 \mathrm{~V} & 13.52 \mathrm{~V} & 1.10 \mathrm{~A} \\ 16.11 & 14.00 \mathrm{~V} & 13.60 \mathrm{~V} & 0.98 \mathrm{~A} \\ 16.48 & 14.00 \mathrm{~V} & 13.68 \mathrm{~V} & 0.92 \mathrm{~A} \\ 17.34 & 14.00 \mathrm{~V} & 13.76 \mathrm{~V} & 0.87 \mathrm{~A} \\ 18.12 & 14.00 \mathrm{~V} & 13.84 \mathrm{~V} & 0.76 \mathrm{~A} \\ 19.25 & 14.00 \mathrm{~V} & 13.91 \mathrm{~V} & 0.76\end{array}$

\section{KESIMPULAN}

Desain sistem konversi energi angin dengan menggunakan PMSG yang terhubung dengan baterai telah dijelaskan pada artikel ini. Sistem turbin angin terhubung dengan beban lampu DC. Mikrokontroller digunakan sebagai pusat pengolah data untuk mengatur sistem turbin angin dan menghasilkan sinyal duty cycle sinyal PWM untuk konverter. Rangkaian konverter dirancang dengan menggunakan satu buah Mosfet dengan mengatur duty cycle. Nilai duty cycle PWM dibawah $40 \%$ maka rangkaian konverter akan mengosongkan baterai, sedangkan pada saat duty cycle diatas 40\% maka rangkaian konverter akan mengisi baterai, sehingga tegangan keluaran mendekati 14V. Pengontrolan suplai tegangan pada beban agar tetap stabil yaitu dari dua buah sumber yaitu dari prototipe turbin angin dan baterai. Pada saat putaran angin dapat menghasilkan tenaga listrik yang baik maka tegangan untuk beban akan disuplai dari prototipe turbin angin tersebut. Namun jika tenaga listrik yang dihasilkan kecil, maka tegangan untuk beban akan disuplai dari baterai.

\section{UCAPAN TERIMA KASIH}

Terimakasih diucapkan kepada Politeknik Negeri Malang yang telah mendanai penelitian sehingga dihasilkan artikel ini. Penulis juga mengucapkan terima kasih kepada beberapa pihak yang telah membantu penyelesaian penelitian dan penulisan artikel ini

\section{REFERENSI}

[1] BPPT, “outlook energy Indonesia 2016 - Google Search.” [Online]. Available: https://www.google.co.id/?gws_rd. [Accessed: 30-Apr2017].

[2] Kementrian ESDM, "Indonesia_Energy_Outlook_2013.pdf." [Online]. Available: https://www.esdm.go.id [Accessed: 30-Apr2017].

[3] M. Nasiri, J. Milimonfared, and S. H. Fathi, "Modeling, analysis and comparison of TSR and OTC methods for MPPT and power smoothing in permanent magnet synchronous generator-based wind turbines," Energy Convers. Manag., vol. 86, pp. 892-900, Oct. 2014.

[4] S. G. Varzaneh, G. B. Gharehpetian, and M. Abedi, "Output power smoothing of variable speed wind farms using rotor-inertia," Electr. Power Syst. Res., vol. 116, pp. 208-217, Nov. 2014.

[5] Y. Xia, K. H. Ahmed, and B. W. Williams, "Wind Turbine Power Coefficient Analysis of a New Maximum Power Point Tracking Technique,” IEEE Trans. Ind. Electron., vol. 60, no. 3, pp. 1122-1132, Mar. 2013.

[6] Y. Errami, M. Ouassaid, and M. Maaroufi, "Optimal Power Control Strategy of Maximizing Wind Energy Tracking and Different Operating Conditions for Permanent Magnet Synchronous Generator Wind Farm," Energy Procedia, vol. 74, pp. 477-490, Aug. 2015. 
[7] M. A. Tabrizi and G. Radman, "Detailed dynamic modeling of Permanent Magnet Synchronous machine based wind turbine for power system dynamic analysis," in 2013 Proceedings of IEEE Southeastcon, 2013, pp. 1-6.

[8] A. Ali, A. Moussa, K. Abdelatif, M. Eissa, S. Wasfy, and O. P. Malik, "Comparative performance of wind turbine driven PMSG with PIcontrollers tuned using heuristic optimization algorithms," in Energy Conference (ENERGYCON), 2014 IEEE International, 2014, pp $120-126$.

[9] J. Chen, T. Lin, C. Wen, and Y. Song, "Design of a Unified Power Controller for Variable-Speed Fixed-Pitch Wind Energy Conversion System," IEEE Trans. Ind. Electron., vol. 63, no. 8, pp. 4899-4908, 2016.

[10] Y. Zou and J. He, "Comprehensive modeling, simulation and experimental validation of Permanent Magnet Synchronous generator wind power system," in 2016 IEEE/IAS 52nd Industrial and Commercial Power Systems Technical Conference (ICPS), 2016, pp. $1-9$.
[11] H. Q. Minh, N. Frederic, N. Essounbouli, and H. Abdelaziz, "A new MPPT method for stand-alone wind energy conversion system," in 2012 2nd International Symposium on Environment Friendly Energies and Applications (EFEA), 2012, pp. 335-340.

[12] Wu Bin, Lang Y., Zargari N., Kouro S. Power Conversion And Control of Wind Energy System. IEEE Press. John Wiley \& Sons Publication, 2011

[13] L. Jiang, C. C. Mi, S. Li, M. Zhang, X. Zhang dan C. Yin, "A Novel Soft-Switching Bidirectional DC-DC Converter With Coupled Inductors," IEEE Trans. Ind. Appl., vol. 49, no. 6, pp. 2730-2740, November/December 2013.

[14] F. Krismer, J. Biela dan J. W. Kolar, "A Comparative Evaluation of Isolated Bi-directional DC/DC Converters with Wide Input and Output Voltage Range," dalam IEEE Industry Applications Conference, Kowloon, Hong Kong, China, 2005.

[15] Mochamad Ashari, "Sistem Konverter DC, Desain Rangkaian Elektronika Daya”. ITS Press, 2012, hal 90-112. 